\title{
ЦАРИЦЫ СИБИРСКИЕ
}

\author{
А.В. Беляков \\ Институт российской истории РАН \\ Москва, Российская Федераџия \\ belafeb@gmail.com
}

Цель: проанализировать все имеющиеся в нашем распоряжении исторические свидетельства о сибирских царицах и царевнах - женах и дочерях сибирского хана Кучума - плененных в августе 1598 г. При этом нас в первую очередь интересовала информация об их происхождении и том, как сложилась их судьба в России.

Материаль исследования: мы обладаем ограниченным количеством документов по истории сибирских цариц рубежа XVI-XVII вв. Помимо нескольких вновь обнаруженных документов, автор обратился к оригиналам архивных памятников изданных в первой половине XIX в. При этом было обнаружено, что издатели в ряде мест исказили первоначальный текст. Они проигнорировали правку и более поздние приписи на полях. В отдельных местах текст подвергся редактированию, дабы сделать его более понятным. В результате этого оказалось, что исследователи почти 200 лет использовали в своих исследованиях дефектные источники.

Результаты и научная новизна: было установлено, что как минимум две супруги хана Кучума происходили из рода казахских Шибанидов, а касимовский царь Ураз-Мухаммед б. Ондан являлся пасынком хана. Еще одна из цариц была родом из чатских мирз. Плененные женщины с трудом уживались все вместе в России. Причины разногласий следует искать еще в событиях их сибирской жизни.

Заполучив столь значительное число знатных пленников, в Москве предприняли попытку использовать женщин для замирения их родственников оставшихся в Сибири. Данный проект не удался по двум причинам: 1) слабой информированности в Кремле об особенностях устройства Сибирского ханства, 2) начавшихся вскоре событиях Смутного времени. В России многие из женщин были выданы замуж за сибирских и ургенчских Чингизидов и ногайских мирз.

Было сделано предположение о том, что брачная политика сибирских Шибанидов в целом была типичной для государств Востока. Наиболее схожа она с матримониальной политикой крымских Гиреев. Полученные данные позволили поставить вопрос о возможности реконструкции персонального состава двора хана Кучума в конце XVI в.

Ключевые слова: Кучумовичи, Сибирское ханство, Московское государство конца XVI - первой половины XVII в., Казахское ханство, ногайские мирзы

Для цитирования: Беляков А.В. Царицы сибирские // Золотоордынское обозрение. 2019. Т. 7, № 2. С. 372-391. DOI: 10.22378/2313-6197.2019-7-2.372-391 


\title{
SIBERIAN QUEENS
}

\author{
A.V. Belyakov \\ Institute of Russian History of the Russian Academy of Sciences \\ Moscow, Russian Federation \\ belafeb@gmail.com
}

\begin{abstract}
Research objectives: To analyze all historical evidence we have about the Siberian queens and princesses - the wives and daughters of the Siberian Khan, Kuchum captured in August 1598. At the same time, this work was primarily interested in information about their origins and how their fate in Russia unfolded.

Materials: There are more than a limited number of documents on the history of the Siberian queens at the turn of the $16^{\text {th }}-17^{\text {th }}$ centuries. In addition to several newly discovered documents, the author turned to the originals of the monuments published in the first half of the $19^{\text {th }}$ century. It was found that publishers had distorted the original text in a number of places. They ignored revisions and later marginal notes. In addition, in some places the text has undergone editing in order to make it more understandable. As a result, it turned out that for almost 200 years researchers used a defective source in their research.

Results and novelty of the research: It was established that at least two queens of Kuchum Khan came from the lineage of the Kazakh Shibanids, and Kasimov's king, UrazMuhammed b. Ondan, was Kuchum's stepson. Another one of the queens was from the Chatsky Mirzas. The captive women got along with overall difficulty in Russia. The reasons for their difficulties should be sought in the events of their Siberian life.

Having obtained such a significant number of noble captives, Moscow attempted to use them to pacify their relatives who remained in Siberia. This project failed for two reasons: 1) poor awareness in the Kremlin about the features of the social structure of the Siberian khanate and 2) the events of the Time of Troubles began soon after the women's capture. In Russia, many of these women were married to the Siberian and Urgench Chinggisids and the Nogai Mirzas.

It was assumed that the marriage policy of the Siberian Shibanids in general was typical of the states of the East. At the same time, it was most similar to the matrimonial policy of the Crimean Gireys. The data obtained thus far allows us to raise the question of the possibility of reconstructing the personal composition of the court of Kuchum Khan at the end of the $16^{\text {th }}$ century.
\end{abstract}

Keywords: Kuchumovichi, Siberian Khanate, Moscow State of the end of the $16^{\text {th }}$ the first half of the $17^{\text {th }}$ century, Kazakh Khanate, Nogai Mirzas

For citation: Belyakov A.V. Siberian Queens. Zolotoordynskoe obozrenie $=$ Golden Horde Review. 2019, vol. 7, no. 2, pp. 372-391. (in Russian) DOI: 10.22378/23136197.2019-7-2.372-391

В последнее время была проделана значительная работа по уточнению генеалогии и брачных связей сибирских Шибанидов [14; 17; 28; 39]. Однако здесь по прежнему существует значительное количество белых пятен, закрыть которые не так то просто. Используя новые архивные находки, мы попробуем выяснить судьбу жен, дочерей и невесток хана Кучума плененных в августе 1598 г. и вывезенных в Россию. К тому же собранный нами материал позволяет прояснить роль гаремов хана и его сыновей в создании жизнеспособной модели сибирской государственности.

В России рассматриваемого времени существовало правило по которому дочери татарских царей и царевичей после замужества назывались царицами, 
даже если их супруг не имел никакого отношения к царскому роду. Поэтому мы и вывели в заголовок это словосочетание - царицы сибирские.

Различные аспекты заявленной темы, не смотря на ограниченный круг источников, большинство из которых введены в научный оборот, уже неоднократно становились предметом специальных исследований. Однако сравнение подлинных архивных дел (в данном случае «Приезд в Москву взятых в полон в Сибири царя Кучума жен и детей в провожании воеводы из Тару ${ }^{1}$ Воейкова, и дача им жалованья и поденного корму» ${ }^{2}$, с его публикацией в XIX в. [5, с. $1-$ 21]) показывает значительное расхождение в тексте. Дело в том, что подборка архивных документов представляет собой в большинстве случаев «отпуски» со значительной редакторской правкой. При этом издатели не только не отображали зачеркнутые места и разнообразные приписи на полях документов, но и целенаправленно искажали в ряде случаев текст, дабы он выглядел единым целым. В результате этого исследователи вот уже почти 200 лет используют в своих работах дефектный источник. Это, в частности, привело к ложным утверждениям о пленении царевича Арслана б. Али в 1598 г. Поэтому мы пришли к необходимости заново проработать текст подлинника. Тем более, что некоторые документы дела оказались неизданными.

Из источника нам становится известно, что в 1599 г. в Москву попали следующие женщины. 8 жен Кучума: 1-я царица Салтаным, 2-я (другая) царица Сюйде-джан (Сюндю-джан, Сюидкождей, Сюим), 3-я царица Ян-девлет (Зендевлет), 4-я царица Ак-тулун (Ян-телун), 5-я царица Ак-Сюйрюк, 6-я царица Шевлей, 7-я царица Кубил (Кубул, Левкал?), 8-я царица Чепшан (Шопшан). 8 дочерей: Тулунбек 3-х лет (от Салтаным); Дурпадша (Тюрчак) 10 лет, Мундур (Мулдур) 6 лет и Карачай 3-х лет (от Сюйде-джан, Сюим); Гулсыфат (Егуп ${ }^{3}$, Чеум $\left.^{4}\right) 14$ лет (от Ак-тулун); Ак-ханым 3-х лет (от АкСюйрюк); Азеп-салтан (Азем-салтан, Салтан) 10 лет (от Шевлей); Кумыз (Кумызяк) 12 лет. 2 невестки царя: жена царевича Арслана - царица Кандаза (Хандаза), дочь ногайского бия Дин-Ахмеда б. Исмаила; жена царевича Каная - царица Данай (Танай), дочь ногайского бия Уруса б. Исмаила. Внучки: Лалтак - дочь ногайского мирзы Бегая (Бая) б. Ханбая б. Исмаила; Ханымджан - дочь царевича Али; две дочери царевича Каная - Навруз-бике (1 год?) и Ак-ханым (Сакныш ${ }^{5}$, Акныша, Акняша). Далее в документах дочери Каная по неизвестным причинам фигурируют по одной. Однако и другие дети, в особенности малолетние, в источниках фиксируются далеко не всегда. В данном случае Навруз, по-видимому, вскоре умерла. Также следует сказать о возрасте детей. Его определяли весьма приблизительно. Он был нужен в Москве зимой 1599 г. только для того, чтобы подготовить пленным богатые шубы для торжественного въезда в столицу ${ }^{6}$. Позднее же требовался для назна-

\footnotetext{
${ }^{1}$ Так в архивной описи.

${ }^{2}$ РГАДА. Ф. 131. ОП. 1. 1598 г. Д. 2.

${ }^{3}$ РГАДА. Ф. 131. Оп. 1. 1600 г. Д. 1. Л. 3.

${ }^{4}$ РГАДА. Ф. 131. Оп. 1. 1600 г. Д. 1. Л. 5.

${ }^{5}$ РГАДА. Ф. 131. Оп. 1. 1601 г. Д. 2. Л. 1.

${ }^{6}$ Следует обратить внимание на интересный факт: все сопровождавшие царскую семью сибирские служилые люди при въезде в столицу должны были одеть свои шубы вывернув их наизнанку: «А которые едут с царицами, и тем всем велеть шубы наделать выварачивая, подпоясався.» [РГАДА. Ф. 131. Оп. 1. 1598 г. Д. 2. Л. 28]. По-видимому, в
} 
чения поденного корма и питья. Маленьким детям еду давали с убавкой по сравнению со взрослыми и подростками.

Как же сложилась дальнейшая судьба этих женщин? Постараемся ответить на этот вопрос. Первоначально цариц планировали разместить в Москве по дворам. Их предполагалось расселить парами со своими дочерьми и малолетними сыновьями следующим образом. На первом дворе должны были поместить цариц Салтаным и Сюйде-джан, на втором невесток Кучума, на третьем царицу Ян-девлет и малолетних детей мирзы Бегая, на четвертом цариц Ак-тулун и Кубул, на пятом Ак-сюйрюк и Чепшан, на шестом царицу Шевлей. Здесь сразу следует отметить, что первые издатели документа пропустили очень важную припись в самом начале первого листа: «Ся роспись имяна подлинно всем им, жонкам. А стоять и корм не по тому дан» ${ }^{7}$. Все планы Москвы разбились о внутрисемейные дрязги. Среди женщин существовало, как минимум, три группировки, которые, судя по всему, не очень мирно уживались друг с другом. То, что воспринималось нормальным в условиях длительного и тяжелого путешествия, было нестерпимо при совместном ведении хозяйства. У нас имеется возможность выделить эти группы и отчасти определить природу разногласий между ними.

Уже осенью 1600 г. ряд цариц подали челобитные на имя московского царя, в которых попросились на житье к касимовскому царю Ураз-Мухаммеду б. Ондану в Касимов или сибирскому царевичу Мухаммед-Кулу б. Ахмад-Гирею (Атаулович) в Городецк (ныне г. Бежецк) или в его обширное поместье в уезде Бежецкий Верх. Борис Годунов дал свое согласие на переезд. Царицы разделились следующим образом. В Касимов отправились царица Сюим (Сюйде-джан) с тремя дочерьми - Дурпадшой, Мулдур и Карачаей, царица Зендевлет (Ян-девлет) и дочь Кучума Кумыз ${ }^{8}$. При этом нам становится известно, что Сюйде-джан являлась мачехой Ураз-Мухаммеда, а значит в первом браке была за его отцом, казахским царевичем Онданом б. Шигаем. Царевна Кумыз же приходилась касимовскому царю двоюродной сестрой. Таким образом и сам Ураз-Мухаммед имел самое прямое отношение к Кучумовичам, ведь он был пасынком сибирского хана. Если же царевна Кумыз (Комызяк) одновременно приходится дочерью Кучуму и двоюродной сестрой Ураз-Мухаммеду, то жены Кучума и Ондана б. Шигая должны быть родными сестрами. По утверждению автора «Сборника летописей» («Жами ат-таварих») Кадыр-Али бека б. Хошум-бека, мать Ураз-Мухаммеда являлась дочерью Булат-султана б. Усяк-хана б. Джанибека [19, с. 125, 365]. Таким образом, мы установили происхождение еще одной, анонимной, жены Кучума. Но стоит подробнее остановиться на Ондане. Дело в том, что в одном из документов падчерица касимовского царя Арслана б. Али, Ай-ханыш, называется дочерью Ондана б. Шигая. При этом Ондан назван ногайским царем [6, с. 21;

столице к этому времени сложилось определенное представление как должны выглядеть коренные сибирские жители. М. Груневег так описывает их в июле 1585 г.: «Тогда же в плену в Москве находился один Языческий Царь (Мухаммед-Кул б. Ахмад-Гирей? А.Б.), его челядь носила своеобразную одежду из пестрого меха» [21, с. 235].

${ }^{7}$ РГАДА. Ф. 131. Оп. 1. 1598 г. Д. 2. Л. 31-35.

${ }^{8}$ РГАДА. Ф. 131. ОП. 1. 1600 г. Д. 1; Д.Н. Маслюженко и Е.А. Рябинина ошибочно называют царевну Кумыз дочерью царицы Сюим [28, с. 105]. Однако это единственная царевна, плененная без матери. Она, по-видимому, к этому времени уже умерла. 
13, с. 103,104$]^{9}$. Подобное было возможно только в том случае, если во второй половине XVI в. в Ногайской Орде возродилась практика провозглашения при бие того или иного «карманного» Чингизида царем. Таким образом у нас появился еще один «ногайский след» в брачной политике Кучума.

В те времена в браках владетельных государей ничего не происходило спонтанно. Каждый шаг серьезно обдумывался. В России эта практика также сохранялась. Поэтому брак молодого царя Арслана на престарелой матери своего касимовского предшественника (царя Ураз-Мухаммеда б. Ондана), царице Алтын-ханум был не случаен. Тем самым он обеспечивал достойную старость родной сестре одной из своих бабок. Да и Ай-ханыш нашли достойного брачного партнера. Она станет супругой сибирского царевича Мухаммед-Кула б. Ахмед-Гирея ${ }^{10}$. После смерти царевича она жила в Ярославле с поденным кормом в 30 копеек, который позднее сократят до 20 копеек. Умерла и похоронена в Касимове в 1651-1652 г. в текие ургенчского (хивинского) царевича Авган-Мухаммеда б. Араб-Мухаммеда, построенном его вдовой царицей Алтын-ханым, дочерью царевича Хаджима (Азима) б. Кучума и падчерицей Арслана б. Али [40]. Другой супругой царевича, по-видимому, одновременно, станет родная дочь Арслана от Фатимы-салтан Шакуловой Алма-бике ${ }^{11}$. До этого казахско-сибирские матримониальные связи ограничивали браком АхмедГирея б. Муртазы на дочери казахского хана Шигая, а также не подтвержденным документально утверждением, что жена Кучума Лайла также приходилась дочерью этому же казахскому хану $[28, \text { с. } 105,106]^{12}$. Теперь же мы имеем двух документально подтвержденных сибирских цариц казахского происхождения. Тем самым следует пересмотреть отдельные сюжеты как истории Сибири, так и сибиро-казахских отношений.

Но вернемся к женщинам, решившим покинуть столицу. К МухаммедКулу отправились царицы Салтаным, Ак-тулум, Ак-сюрюк и Шевлей. С Аксюйрюк отправились и ее внуки, дети Бегай мирзы. Таким образом нам становится известно, на чьей дочери был женат мирза. В Москве решились остаться Левкал (Кубул?) и две невестки сибирского хана ${ }^{13}$.

Как мы видим, составители первоначальной росписи, по которой следовало расселить цариц по дворам, даже не пытались разобраться в хитросплетениях семейных связей и, не хотя этого, разлучили бабку с внуками.

Но если мы сравним все списки, имеющиеся в нашем распоряжении, то можем заметить, что в них не отмечена еще одна царица - Чепшан (Шопшан). Нам известно, что в это время она еще было жива. 1 августа 1601 г. ее имя фигурирует среди иных московских цариц, подавших челобитную на выдачу им денег на зимнее и летнее платье $\mathrm{e}^{14}$. Царица, по-видимому, проживала у своего сына, царевича Абу-л-Хайра б. Кучума, плененного еще в

${ }^{9}$ РГАДА. Ф. 134. Оп. 1. 1630 г. Д. 1. Л. 7, 31, 53; Ф. 131. Оп. 1. 1650 г. Д. 6. Л. 1; Ф. 141. ОП. 1. 1624 г. Д. 1.

${ }^{10}$ РГАДА. Ф. 131. ОП. 1. 1650 г. Д. 6. Л. 1.

${ }^{11}$ РГАДА. Ф. 131. Оп. 1. 1623 г. Д. 10. Л. 8.

12 Это сохранившееся в семейных преданиях известие на самом деле может быть искусственным конструктом, составленным в целях возвеличивания своего рода.

${ }^{13}$ РГАДА. Ф. 131. ОП. 1. 1600 г. Д. 1.

${ }^{14}$ РГАДА. Ф. 131. Оп. 1. 1601 г. Д. 2. Л. 5. 
1591 г. Вскоре после приезда матери его крестили (23 сентября 1599 г.) [4, c. 396]. Теперь он стал Андреем Кучумовичем (Кучумовым).

Зато из документов исчезает имя другой царицы - Кубул (Левкал). Вполне возможно, что это следует рассматривать как констатацию ее смерти. Однако в другой выписи, созданной около 1604 г., рядом с ее именем не стоим пометы о смерти, хотя они имеются рядом с именами иных, умерших к этому времени людей. К судьбе этой царицы мы еще вернемся ниже.

Какие еще сведения есть у нас о женах и дочерях Кучума? Все в том же деле о приезде плененных цариц имеется еще одна незафиксированная издателями XIX в. приписка, сделанная иными чернилами и почерком несколько позднее составления самого документа: «Четвертой царице, Актолун чаского ...» ${ }^{15}$. Она имеет для нас очень большое значение, так как указывает на происхождение царицы как дочери чатского князя. Более того, сохранились письменные свидетельства о том, что ее отец или брат просили московского царя отдать ему царицу с дочерью Гулсыфат (Егуп, Чеум). В грамоте от чатских (жагацких) мирз Федору Ивановичу читаем: «И будет похотите с нами в зговоре быть, и нашево племяни две души попали к вам. И вы бы их к нам прислали» $[37, \text { с. } 128]^{16}$. При описании в XVIII в. документ был датирован 1597 г. До последнего времени датировка не подвергалась сомнениям у исследователей. Однако у нас есть возможность значительно скорректировать ее. Сразу же за поражением Кучума 20 августа 1598 г., тарский воевода C.В. Кузьмин уже 23 августа послал в Чаты захваченного тогда же сибирского сеида Тулмаметя «проведывать про Кучюма царя, жив ли он, или утоп», «да х Кожбахтею мурзе с товарыщи, чтобы оне, все чатцкие люди, были под твоею царьскою высокою рукою». 5 октября сеид вернулся с грамотою от чатских князя и мирз в Тару. 17 октября ее перевод уже был послан в Москву $^{17}$. Таким образом нам понятнее становятся взаимоотношения Кучума и Чатов. Жившие при слиянии рек Оби и Томи, они находились в вынужденном военном союзе или даже вассалитете по отношению к сибирскому хану. Союз был подкреплен династическим браком. Нужно помнить еще два момента. Уже упоминаемый нами хан Шигай имел жену из Чат $[28$, с. $105 ; 5$, c. 58-59]. К тому же, как отметил В.В. Трепавлов, чаты издревле служили казахским ханам: «Наперед сево служивали есмя Урус царевым детям, а после сложились с Кучумом царем» $[38, \text { с. } 53 ; 37 \text {, с. } 128]^{18}$.

Последний факт проливает свет на значение гарема Кучума и, возможно, отдельных его сыновей. Браки на дочерях наиболее значимых региональных лидеров Сибири должны были упрочить власть Шибанидов. Теперь становится понятным, почему гарем в августе 1598 г. находился с Кучумом. Это была его самая большая ценность. Жены фактически находились на положении заложниц и призваны были быть более сговорчивыми их отцов и братьев. Это, однако, далеко не всегда срабатывало. В особенности на позднем этапе. Достаточно вспомнить все ту же позицию Чатов, не спешивших на помощь сибирскому хану в августе 1598 г. По-видимому, Ак-тулун была не одинока, среди плененных в 1598 г. цариц могли быть и другие женщины с подобным

\footnotetext{
${ }^{15}$ РГАДА. Ф. 131. Оп. 1. 1598 г. Д. 2. Л. 61.

${ }^{16}$ РГАДА. Ф. 131. Оп. 1. 1597 г. Д. 2. Л. 1.

${ }^{17}$ РГАДА. Ф. 131. ОП. 1. 1598 г. Д. 2. Л. 1-2.

${ }^{18}$ РГАДА. Ф. 131. Оп. 1. 1597 г. Д. 2. Л. 1.
} 
статусом. Их следует искать среди тех, что отправились жить к МухаммедКулу. Данный факт говорит и о том, что у племянника Кучума были, как минимум, ровные отношения с этой группой своих теток. Также понятна и неприязнь к родственницам возможных убийц его отца. По одной из версий Ахмад-Гирей б. Муртаза был убит по распоряжению своего тестя, будущего казахского хана Шигая [28, с. 105].

В России судьба цариц ничуть не изменилась. Они по-прежнему оставались знатными заложницами. Однако теперь Москва стремилась разыграть женскую карту при замирении и подчинении их отцов и братьев. Вопрос - на сколько эффективно и грамотно?

Несколько иной выглядит политика Кучума по отношению к своим дочерям. Посредством браков с ними хан стремился заручиться поддержкой своего ближайшего окружения и выходцев из Средней Азии. Известно, что сибирский сеид, ургенчский выходец, хаджа Дин-Али б Мир-Али был женат на дочери Кучума Нал-ханише, рожденной от брака с царицей Лилилак, как мы уже говорили, возможно, дочерью казахского хана Шигая. Сеид, в частности, возглавлял дипломатические миссии от имени бухарского хана Абдаллаха, поэтому часто отсутствовал. Его жена постоянно находилась при отце. Нечто подобное мы наблюдаем и с женой сына Кучума царевича Азима (Хаджима). Он женат на дочери абыза Ибердея (Игибердея) Карачай (Карачаца). Абыз также возглавлял бухарские посольства. И в первом и во втором случае человек оказывался привязан посредством брака к ханской семье [17, с. 235-236].

Также Кучум активно роднился с ногайскими мирзами [28, с. 105-106]. Могли ли среди плененных жен Кучума находиться дочери ногайских мирз? Полностью отвергать это предположение нельзя. Однако против этого имеется серьезный аргумент. Дело в том, что документы регулярно сообщают о ногайском происхождении его двух невесток. Если бы таковые имелись и среди жен хана, об этом также обязательно сообщили бы. В Кремле была важна любая информация. В Москве практически не разбирались в сибирских реалиях. Поэтому и отсутствует информация о родственных связях плененных жен сибирского хана. Имя того или иного сибирского мирзы или даже князя ничего не говорило в столице. Пример с Чатами в данном случае уникален. Приписка на документе появилась, по-видимому, в связи с тем, что с родственниками царицы после грамоты 1598 г. осуществлялись какие то контакты. Хотя письменных свидетельств об этом до наших дней не сохранилось.

Д.Н. Маслюженко и Е.А. Рябинина собрали сведения о иных браках Кучумовичей на представителях сибирской элиты. По сообщениям С.У. Ремезова, одной из жен Кучума была дочь сибирского мирзы Девлетима, городок которого располагался непосредственно рядом с Искером ${ }^{19}$. В 1607 г. один из лидеров сибирского тюркского племени мякотин (бикотин) Евлубай являлся тестем царевича Чувака б. Кучума. Евлубай кочевал вместе с братом своего зятя, Азимом, хотя их отношения, видимо, не сложились, поскольку он увел свою и еще 11 татарских семей на Убаган (Обага река), где их пограбил дядька царевича Алтаная Боишан с калмыками. В результате Евлубай пришел в

${ }^{19}$ Тут напрашивается аналогия с родом мирз Яшлавский (Сулешевых в русских источниках). Бахчисарай и Чуфут-Кале располагались на их, а не на ханских землях. Яшлавские фиксируются в источниках как особо доверенные лица крымских ханов. 
Тюмень на «государево имя». Эти же исследователи считают представителями родовой сибирской знати и мирз Карамышевых - Мусаитовых [28, с. 107]. Здесь, однако, не все так ясно с происхождением и статусом как Карамыша, так и его отца Мусаита [7]. При этом нужно отметить, что данный род, судя по источникам, связан не только с женой царевича Мухаммед-Кула б. АхмедГирея, но и с другими сибирскими царицами ${ }^{20}$.

Благодаря последним архивным изысканиям, нам удалось установить иных ближайших родственников вывезенных цариц. Так, явно в родстве с кемто из четырех сибирских цариц (Салтаным, Ак-тулум, Ак-сюйрюк или Шевлей) находился мирза (князь) Байтерек Чеплемышев сын. Его потомок, Иштерек Байтереков стал кормовым иноземцем Посольского приказа и проживал в Касимове, а затем в Ярославле $[10]^{21}$. Где, кстати, жили большинство представителей сибирской знати, в том числе царицы и царевичи. Другой же сибирский татарин, абыз Безерген Байцын, родоначальник семьи переводчиков Посольского приказа [39, с. 386-387; 11, с. 283], в своей челобитной утверждал что «выехав, пристал к сибирскому царевичю к Маметкулу Атауловичю, потому что большая ево царица, Алма-биим, мне двоюродная сестра» ${ }^{22}$. Данное сообщение позволяет попытаться определить предков Безергена. Нам известно, что старшая жена царевича Мухаммед-Кула являлась дочерью некоего Карамыша Мусаитова, женатого на дочери сибирского сеида Дин-Али ходжи. ДинАли в свою очередь женат на дочери хана Кучума Нал-ханише. Если Безерген и Алма-бике двоюродные брат и сестра по мужской линии, то его отец (Байц, Байца?) должен быть родным братом Карамыша Мусаитова. Если же родство по женской линии, то мы попадаем в тупик. Таким образом, мы должны признать, что не можем однозначно утверждать о том, кто являлся предками Безергена. Он мог быть как выходцем из Средней Азии (сартом), составлявшем костяк окружения Кучума, так и представителем сибирской родоплеменной знати, посредством браков на дочерях которых сибирские Шибаниды поддерживали единство своего государства. В любом случае Безерген относился к представителям элиты Сибирского ханства. По косвенным данным, упоминание о нем как об абызе и дипломатические посылки в Бухару к хану Абдаллаху, мы склоняемся к его среднеазиатскому происхождению.

Также трудно представить функционирование Сибирского ханства без каких либо брачных связей с представителями прежней правящей династии (Тайбугиды), а также с сибирским карачей Маметом (Мухаммедом) [8]. Но каких-либо свидетельств о подобных браках у нас на данный момент нет.

Помимо этого в нашем распоряжении, по-видимому, имеется свидетельство о еще одном браке царевны из сибирских Шибанидов на одном из представителей сибирской родоплеменной верхушки. В писцовой книге Коломенского уезда отмечен некий сибирский мирза Карамыш и его жена княгиня Суньяша. В 1577/78 г. они оба были уже мертвы. При этом Карамыш умер ранее. Таким образом, появиться в России Карамыш и Суньяша должны были где-то в период 1550-1560-х гг. За Суньяшей значилось довольно обширное

\footnotetext{
${ }^{20}$ РГАДА. Ф. 131. Оп. 1. 1698 г. Д. 2. Л. 57.

${ }^{21}$ РГАДА. Ф. 131. Оп. 1. 1598 г. Д. 2. Л. 58-66; 1629 г. Д. 3. Л. 1-2.

${ }^{22}$ РГАДА. Ф. 131. Оп. 1. 1627 г. Д. 7. Л. 1.
} 
прожиточное поместье в 343 чети $[34, \text { с. 472, 543-544] }]^{23}$. Из-за значительной временной разницы данный Карамыш не мог быть упоминаемым нами Карамышем Мусаитовым. По мнению М.В. Моисеева, появление этой группы татар в Коломенском уезде связано с событиями 1563 г., когда Шибаниды сместили с престола Сибирского ханства Тайбугидов. Тогда жена последнего правителя, Ядгара б. Касима (Гази), дочь ногайского бия Исмаила, и ее ононимный сын оказались в России. Иван IV писал Исмаилу: «А дочери твоей, которая была за сибирским князем, и сына ее, а твоего внука, тебе не отпустили». С ними, вероятно, бежала и часть двора Ядгара (Едигера) [31, с. 240; 27$, с. $123-124]^{24}$. У данного предположения имеются и слабые стороны. Размеры прожиточного поместья указывают на то, что поместье Карамыша составляли от 1700 до 3400 четей (при расчете, однако, использовались законодательные акты первой половины XVII в.). Это соответствовало статусу Чингисидов и отдельных ногайских мирз [14, с. 307-328, 339-342; 3]. Следует обратить внимание на разницу в статусе мужа и жены. Карамыш упомянут как мирза $^{25}$, а его супруга - княгиня. Это должно указывать на их изначально разный социальный уровень. Можно предположить, что статус мужа значительно повысился благодаря его супруге. В таком случае женщина, повидимому, была из рода Чингизидов. В таком случае муж получает почетное звания гургана (зятя Чингизидов) $)^{26}$. При этом брак мог быть заключен как в Сибири, так и уже в России на той же сибирской царевне - к примеру на неизвестной сестре или дочери служилого царевича Шах-Али б. Ак-Даулета. О нем и его жене, возможно, упоминал в своем письме 1570 г. хан Кучум к Ивану IV: «Пяти шти чловеков в поиманье держать, земле в том что? Яз пошлю посла и гостей, да гораздо помиримся, толко похош с нами миру, и ты ис тех людей одного, которые в поиманье сидят, отпусти, и своего человека с ними к нам пришли гонцом» [37, №42, с. 52; 24, с. 888]. Не исключено, что две версии объединяются. Карамыш действительно мог быть сыном князя Ядгара. В таком случае его могли женить на дочери шибанского царевича, дабы подкрепить его претензии на Сибирь: «...и внуком твоим промыслити, чтоб он вперед на том юрте был» ${ }^{27}$. В любом случае пока это только наши предположения. Но Карамыш, безусловно, являлся заметной фигурой в Си-

${ }^{23}$ К примеру дочь астраханского царевича Абдуллы б. Ак-Кобека, вдова романовского мирзы Эля б. Юсуфа Ахтанай (Ульяна) получила на прожиток 500 чети в с. Никольском [32, с. 198; РГАДА. Ф. 131. Оп. 1. 1613 г. Д. 2. Л. 2; 22, с. 348]. Вдове астраханского царевича Арслан-Али б. Абдуле с сыном Кутлуг-Гиреем на пожиток дали село Дубровка Касимовского уезда (624 чети с осьминою) [22, с. 336; РГАДА. Ф. 233. Кн. 19. Л. 71; Ф. 131. Оп. 1. 1695 г. Д. 1. Л. 23; Ф. 159. Оп. 2. Д. 4391. Л. 3].

${ }^{24}$ РГАДА. Ф. 127. Оп. 1. Кн. 6. Л. 176 об.-190 об.

${ }^{25}$ Известные нам документы позволяют предположить, что княжеским достоинством обладал только глава рода, все остальные именовались мирзами. По-видимому, это была общая практика. Мы наблюдаем ее в Ногайской Орде, Крыму и среди темниковских и касимовских татар.

${ }^{26}$ В России XVI-XVII вв. подобные примеры неоднократно фиксируются. Гурганами становились ногайские мирзы и знатные крымские выходцы, к примеру, Пашай мирза Кулюков. Это рассматривалось как особое пожалование от московского государя.

${ }^{27}$ РГАДА. Ф. 127. Оп. 1. Кн. 6. л. 176 об.-190 об. 
бири. Но в таком случае часть служилых татар, испомещенных в Коломенском уезде, также могут оказаться сибирского происхождения.

Приходится констатировать, что в настоящее время наиболее перспективным направлением для дальнейших исследований родоплеменной сибирской элиты является выявление всех родственников сибирских цариц и членов их дворов, а также их потомков ведавшихся в Посольском приказе.

Что нам еще известно о сибирских царицах и царевнах? До июля 1603 г. в Уфе оказались сразу несколько сибирских цариц. По-видимому, это была операция по замирению или же попытке вывоза / добровольного выезда в Россию двух сыновей Кучума - Али и Каная. Именно они посылали проведать про судьбу цариц в «дальную» Кара-Барынскую волость Башкирского уезда своих людей: «как де государь царь и великий князь Борис Федорович всеа Русии царевича Алея з братьею пожалует, к ним в улусы цариц пришлет ли де?» [29, №35]. Поэтому анонимными царицами могли быть только жены этих Чингисидов, царицы Кандаза и Данай. В Сибирь их не отпустили. Мы видим цариц в Москве на следующий 1604 г. Логично предположить, что они вернулись в столицу вместе с добровольно выехавшим царевичем Арсланом б. Али ${ }^{28}$. При этом нам ничего не известно о том, где в это время находились дочери этих цариц. Были ли они отправлены в Уфу или же оставались в Москве, неизвестно. Известно только, что в Сибири цариц ждали вместе с царевичем Янсюером б. Али [30, с. 212].

В первые годы XVII в. в Россию выехал ногайский мирза Бегай (Бай) б. Ханбаяй б. Исмаил, зять Кучума. Нам неизвестно положение мирзы в Сибири. Но он явно сыграл в ее истории свою роль. Возможно, со временем она станет нам понятна. Пока же мы видим, что его дети до 1598 г. проживали у деда с бабкой. После с бабкой, царицей Ак-сюйрюк, они переехали к царевичу Мухаммед-Кулу. Когда их отец оказался в России и был испомещен в Дорогобужском уезде, дети, а, возможно, и царица, по-видимому, переехали к нему. В результате событий Смутного времени семья мирзы оказалась в осажденном Сигизмундом III Смоленске. В августе Бегай со своей семьею бежал из осажденного, на этот раз уже русскими войсками города к боярину и воеводе князю Д.М. Черкасскому. Мы не знаем, пережили ли Смуту царица АкСюйрюк и Лалтак. Однако можно сделать осторожное предположение о том, что внучка Кучума стала супругой одного из потомков азовского выходца Кучума Кизилдеева. Судя по документам, в Дорогобуже и Смоленске было нечто, сильно объединявшее обе семьи. По крайней мере бежали они из осажденного города вместе. Да и далее отмечаются определенные пересечения в судьбах представителей этих родов. Если наше предположение о браке верно, то более всего на роль жениха подходит либо Асан б. Кучум, или его сын Сабай испомещенный в 1613 г. в Суздальском уезде. Отцу назначили тогда поместный оклад 600 четей и 50 рублей годового денежного жалования, а сыну соответственно 500 и 40 - почти предельные оклады для служилых татар, не являющихся представителями владетельного рода [16].

После 1604 г. на целое десятилетие информация о сибирских царицах и царевнах почти полностью пропадает из документов. В эпоху Смуты было не до них. Но есть исключение. Касимовский царь Ураз-Мухаммед регулярно

${ }^{28}$ РГАДА. Ф. 134. Оп. 1. 1622 г. Д. 1. Л. 27-32. 
упоминает своих родственниц и их мужей в переписке с Яном Сапегой. Царь стремился оградить их поместья от каких-либо посягательств со стороны. Перечислим их всех: сестра Бохты царевна Сеиткулова дочь Шепелева, племянники Козяк мирза Сеит-Магметев сын Юсупов [36, №88, с. 119] и Каплан мирза [36, №92, с. 123], зятья Шихим царевич [36, №90, с. 121], Сафаралей мирза Изламов [36, №91, с. 122], шурин Ахмет мирза Алеев [36, №92, с. 123]. Получается, что Ураз-Мухамед постарался выдать замуж всех своих родственниц. Предпримем попытку с их отождествлением.

Сестра царица (царевна) Бохты, по-видимому, являлась супругой ногайского мирзы из Ярославля Сафаралея Изламова. В 1636 г. отмечена вдова некоего Сафаралея (Сафар-Али) мирзы Арасланова сына Шейдяков [14, с. 226, $326]^{29}$. По другим документам нам становится известно имя вдовы - Бохтыханыш, дочь царевича Сеиткула (Сеит-Кула) ${ }^{30}$. В документах известен казахский царевич Сеит-Кул сын Шигай хана $[12 ; 25 \text {, №8, с. 11-12] }]^{31}$. В таком случае нам следует искать некоего Сафар-Али б. Араслана б. Излама (Ислама?). По-видимому, это потомок Саид-Ахмеда б. Мусы. Сафарали мирза был убит 11 декабря 1610 г. в Калуге казаками в отместку за смерть Лжедмитрия II [26, c. 175; 2, №307]. Бохты приходится двоюродной сестрой Ураз-Мухаммеду. Свидетельств о ее связи с Сибирью на настоящий момент у нас нет.

Зять царевич Шихим - шарманшанский царевич Шейх-Мухаммед б Мухаммед $^{32}$. Имя его жены нам неизвестно. Однако она должна быть сестрой или же теткой касимовского царя.

Племянник Козяк мирза Сеит-Магметев сын Юсупов. Он должен быть потомком ногайского бия Юсупа б Мусы. По-видимому, это сын Сеид-Мухаммеда б. Ибрагима б. Юсупа. Сеид-Мухаммед известен как помещик Романовского уезда $[3, \text { с. } 595]^{33}$. О его сыне сведений нет. Нужно сказать, что уже ранее сибирские Шибаниды роднились с этой ветвью потомков Эдиге. Мирза Чин б. Эль б. Юсуп в одном из русских документов назван племянником Кучума ${ }^{34}$. Таким образом, романовский мирза Эль должен был быть женат на сестре сибирского царя. О ее проживании в России, однако, ничего неизвестно.

Племянник Коплан (Каплан) мирза. Где-то в конце XVI в. в России оказались Еналей (Джан-Али) мирза, Каплан мирза и Алей мирза Тугановы дети Шейдяковы, их мать Девлет-тотай и их дядя, Теникей мирза. О Теникее еди-

${ }^{29}$ РГАДА. Ф. 131. Оп. 1. 1636 г. Д. 7. Л. 4; Ф. 141. Оп. 1. 1626 г. Д. 59. Л. 74-82.

${ }^{30}$ РГАДА. Ф. 131. Оп. 1. 1649 г. Д. 7. Л. 1, 3; 1659 г. Д. 6. Л. 1-3; 1640 г. Д. 3. Л. 15.

${ }^{31}$ РГАДА. Ф. 122. Оп. 1. 1594 г. Д. 1.

32 Его происхождение до настоящего времени не выяснено. По-видимому, следует согласиться с мнением И.В. Зайцева, кто делает предположение, что данный не относится к «золотому роду». По мнению исследователя, это скорее выходец из Гиляна. Здесь находились два вассальных по отношению к Персии ханства - Бийэ-пиш («Ближний берег») и Бийэ-пас («Дальний Берег»). После ряда попыток отстоять внутреннюю самостоятельность оба ханства были уничтожены шахом Аббасом в 1590-1592 гг. [23].

${ }^{33}$ В 1570 г. Ибрагим вместе с неназванным сыном после конфликта с Р. Пивовым бежал в Литву. Далее они перебрались в Крым, а затем оказались в Малой Ногайской орде (Казыев улус) [35, л. 4, с. 63]. По-видимому, Сеит-Мухаммед и был тем анонимным сыном. Но в таком случае получается, что беглые мирзы бросили в России своих жен и малолетних детей. Козяк должен был воспитываться у своих романовских родственников.

${ }^{34}$ РГАДА. Ф. 123. ОП. 1. 1586 г. Д. 1. Л. 15-16. 
ножды отмечено, что он Оксаров (Аксаров) сын ${ }^{35}$. Получается, что Девлеттотай, или же еще одна, анонимная жена мирзы, была казахской или же сибирской царицей (царевной). При этом приходилась сестрой (неизвестно в какой степени родства) Ураз-Мухаммеду б. Ондану.

Шурин Ахмет мирза Алеев - это романовский служилый татарин из ногайских мирз Ахмед б. Али б. Кутум, брат жены касимовского царя УразМухаммеда царицы Салтан-бике [18].

Как мы видим, далеко не все перечисленные родственники касимовского царя были напрямую связаны с сибирскими царицами. Однако приведенные нами данные очерчивают общий круг их возможных брачных партнеров. Эти же данные также указывают наиболее перспективные направления архивных изысканий по заявленной нами теме.

Вновь имена сибирских цариц регулярно начинают встречаться на страницах источников только с 1614 г. К этому времени большинство, если не все, жены Кучума уже умерли. А вот о некоторых его дочерях и внучках у нас имеется информация. Когда внук Кучума Арслае б. Али стал касимовским царем, то вокруг него стали собираться его многочисленные родственники. В период его царства (1614 - 02.04.1626 гг.) в Касимове у царя «в шею да в тело» жили его тетки, дочери Кучума Молдур, Тур-пача (Дурпадша) и Нал-бике. Арслан на заднем дворе поставил каждой отдельные хоромы. Там они и жили своим хозяйством, числясь при этом ярославскими кормовыми татарами. После смерти племянника, доходы его наследника, царевича Сеид-Бурхана б. Арслана резко сократились. Родственники касимовского царевича по матери сделали все возможное для того, чтобы сибирские царевны покинули город. В конечном итоге они подали челобитную о дозволении переезда в Ярославль. Правда Нал-беке вскоре отказалась от этого о осталась в Касимове. При этом очень странной выглядит формулировка, почему она хочет этого: «И мне бы, робе твоей, умерети в Косимове у родителей своих» ${ }^{36}$. Быть может в Россию выехала и ее мать, царица Лилилак? Мы уже видели, что имена отдельных женщин из семьи Кучума передавались разными, порой, абсолютно не схожими именами. Быть может Лилилак и Кубул (Левкал) - это одно и тоже лицо? Пока к данному предположению следует относиться очень осторожно. Челобитную явно писал русский человек. Поэтому фраза о смерти у своих родителей, вполне возможно, следует рассматривать только как расхожее выражение. Она получает позволение жить в городе: «и царевич де Сеит-Бурхан по государеву указу ей, царевне Нале-беку, жить у себя велит. А кормить деи и поить, и одевать, и обувать тое царевны Нал-бека царевичю нечем». В документах отмечена как вдова и упоминается до 1651 г. В это время ее поденный корм составлял 18 копеек ${ }^{37}$.

Следует отметить, что о Нал-беке ничего не говорится в документах о выезде 1598 г. Да и она, если считать ее дочерью Лилилак, приходилась Арслану не теткой, а двоюродной сестрой. Возможно, Нал действительно дочь Кучума. Только это родная сестра Али, плененная в марте 1607 г. [30, с. 37] На данном примере мы видим, что из-за скудности источников генеалогия Кучумовичей с трудом подвергается восстановлению.

О Тур-паче нам практически ничего неизвестно. В самом начале 1613 г. ногайский мирза Кара Кель-Мухаммед б. Ураз-Мухаммед просил московских

\footnotetext{
${ }^{35}$ РГАДА. Ф. 131. Оп. 1. 1622 г. Д. 1. Л. 4.

${ }^{36}$ РГАДА. Ф. 131. Оп. 1. 1628 г. Д. 10.

${ }^{37}$ РГАДА. Ф. 131. Оп. 1. 1651 г. Д. 6.
} 
бояр (Михаил Федорович еще не был избран царем) отпустить в Ногайскую Орду некую Дойдур-пашу, обещая за нее щедрый «окуп» [1, с. 82]. В.В. Трепавлов отождествляет ее с одной из дочерей Кучума - Дерпадшой (Тур-пача, Тулун-беке), плененной в 1598 г. Данный факт указывает на то, что дочери сибирских Шибанидов сохраняли «династическую ценность» (по определению В.В. Трепавлова) и после падения Сибирского ханства [39, с. 43]. Просьба мирзы осталась без внимания. Отдавать замуж заграницу в России было непринято. После 1628 г. она не встречается в документах.

В Ярославле Молдур вышла замуж за знатного выходца из Большой Ногайской Орды Девлета (Девлет-Мамет ${ }^{38}$ ) Еналей мирзина сына Шейдякова ${ }^{39}$. В 1625 г. Девлет отмечен как кормовой иноземец в Ярославле ${ }^{40}$. Он умер в Великий пост 1646 г. [14, с. 103] $]^{41}$ От этого брака известна дочь Ирина. Дочь приняла православие в 1652 г. $^{42}$ Царица же встречается в документах до 1671 г. ${ }^{43}$ Получается, что она прожила около 79 лет. В.В. Вельяминов-Зернов отмечает, что в 1651 г., еще при своей жизни она поставила в память о себе надгробную плиту в Касимове, на старопасадском татарском кладбище [20, c. 306-307] $]^{44}$. До 1646 г., когда произошло общее снижение содержания кормовым иноземцам, получала 24,5 копейки в день, далее - по 15 копеек ${ }^{45}$.

Интересно, что у Девлет-Мамета была еще одна жена, касимовская царица Нал-ханиша (Нагел) Карамышева дочь Мусаитова [7], вдова касимовского царя Арслана б. Али и правнучка Кучума [14, с. 299; 6].

Не думаем, что остальные царевны все поумерали в девичестве. С высокой вероятностью их следует искать среди жен служилых ногайских мирз Шейдяковых, Кутумовых, Юсуповых. Некоторые из них могли выйти замуж за служилых царевичей. Так сестра Арслана б. Али, Ханым-джан, и младшая жена шарманшанского царевича Шейх-Мухаммеда б. Мухамеда Ханым, повидимому, одно лицо ${ }^{46}$.

Мы специально не стали рассматривать судьбы всех женщин, в той или иной степени относящихся к Кучумовичам. Их значительное число еще больше усложнило бы общую картину. Данные же по предложенной выборке позволяет сделать определенные обобщения. Заполучив одномоментно такую

${ }^{38}$ РГАДА. Ф. 141. Оп. 1.1622 г. Д. 22.

${ }^{39}$ РГАДА. Ф. 131. ОП. 1. 1631 г. Д. 1. Л. 3.

${ }^{40}$ РГАДА. Ф. 131. ОП. 1. 1625 г. Д. 5.

${ }^{41}$ РГАДА. Ф. 131. Оп. 1. 1650 г. Д. 65. Л. 1; 1652 г. Д. 9. Л. 3; Ф 141. Оп. 1. 1646 г. Д. 113а. Л. 73.

${ }^{42}$ РГАДА. Ф. 131. ОП. 1. 1652 г. Д. 5. Л. 1.

${ }^{43}$ РГАДА. Ф. 131. ОП. 1. 1671 г. Д. 3.

${ }^{44}$ Следует особо остановиться на надгробиях 1651 г. Нам известно о трех таких надгробьях: Молдур, дочери Кучума, Алтын-ханым, дочерью царевича Хаджима б. Кучума и падчерицей Арслана б. Али, и Ай-ханыш, дочери Ондана б. Шигая. При этом все они были созданы еще при жизни женщин, оставшихся к этому времени вдовами. Мы вправе предположить, что это был спланированный шаг, возможно, вызванный общим кризисом в ощущениях знатных мусульман в России и надвигающимися неизбежными переменами [9]. К тому же единственная дочь Молдур вскоре примет крещение, дети Алтын-ханым умерли, а у Ай-ханых их, по-видимому, не было. Они боялись, что достойно проводить их в последний путь будет просто некому.

${ }^{45}$ РГАДА. Ф. 131. Оп. 1. 1671 г. Д. 3; 141. Оп. 2. 1646 г. Д. 113 а. Л. 73.

${ }^{46}$ РГАДА. Ф. 131. Оп. 1. 1623 г. Д. 10, Л. 9. 
большую группу знатных пленниц, в Москве, по-видимому, первоначально обрадовались. Однако вскоре возник логичный вопрос: можно ли их использовать в тех или иных государственных целях, прежде всего в закреплении своей власти в Сибири? На настоящий момент мы имеем однозначные указания о попытке воздействовать на царевичей Арслана и Каная. Что касается оказания давления на сибирскую родоплеменную знать, то с определенными оговорками мы можем говорить только о Чатах. Потенциал иных цариц, повидимому, не осознали. Причин этому две: 1) слабая информированность Москвы о хитросплетениях генеалогических и политических связей народов Сибирского царства; 2) вскоре начавшиеся события Смутного времени, сделавшие на долгие годы не актуальными для руководства России многие сибирские вопросы. А после выхода из Смуты ситуация кардинально поменялась. Тем самым «политический потенциал» сибирских цариц оказался невостребованным. В жестком мужском мире они превратились в своеобразную разменную монету. На первых порах мы можем наблюдать определенный пиетет по отношению к своим родственницам со стороны татарских царей и царевичей (Ураз-Мухаммед б. Ондан, Мухамед-Кул б. Ахмед-Гирей, Арслан б. Али). Но со временем все меняется. В середине века царицы ищут поддержки в первую очередь друг у друга. Теперь они сами должны быть сильными, чтобы не затеряться в жестоком мужском мире. Таким получился, если хотите, женский взгляд на историю Кучумовичей, оказавшихся в России.

Полученные нами результаты также позволяют значительно скорректировать наши представления о брачной политике Кучума. При этом она была не уникальной, а, скорее, типичной для государств Востока. Как прямой аналог здесь можно привести матримониальные связи крымских ханов. По Крыму рассматриваемого нами периода мы имеем значительно больше информации. Поэтому, если допустить, тот факт, что правила формирования ближайшего ханского окружения в Крыму и Сибири были в своей основе типичными, то используя наши сведения о дворах Гиреем, мы сможем частично реконструировать персональный состав двора Кучума. Нам известны, в своем большинстве, только люди из ближайшего окружения сибирских цариц. Но, используя известные наработки по истории Крымского ханства [15; 33] и данные полученные при анализе сведений о женах Кучума, мы можем, по крайней мере, попытаться установить их статус, и, возможно, даже происхождение. Но это уже будет другое исследование.

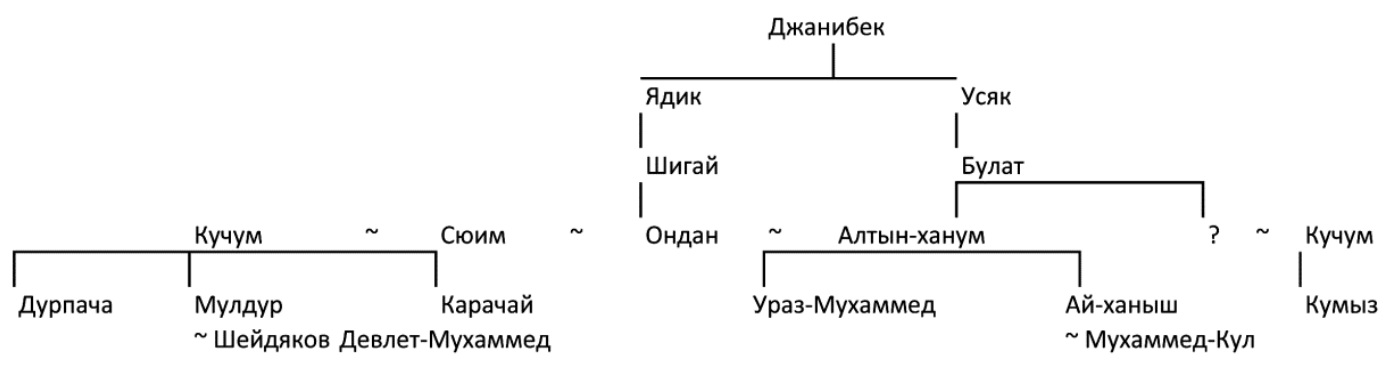

Генеалогические связи сибирских и казахских Шибанидов на рубеже XVI-XVII вв.

Genealogical relations of the Siberian and Kazakh Shibanids at the turn of the $16^{\text {th }}$ and $17^{\text {th }}$ centuries 


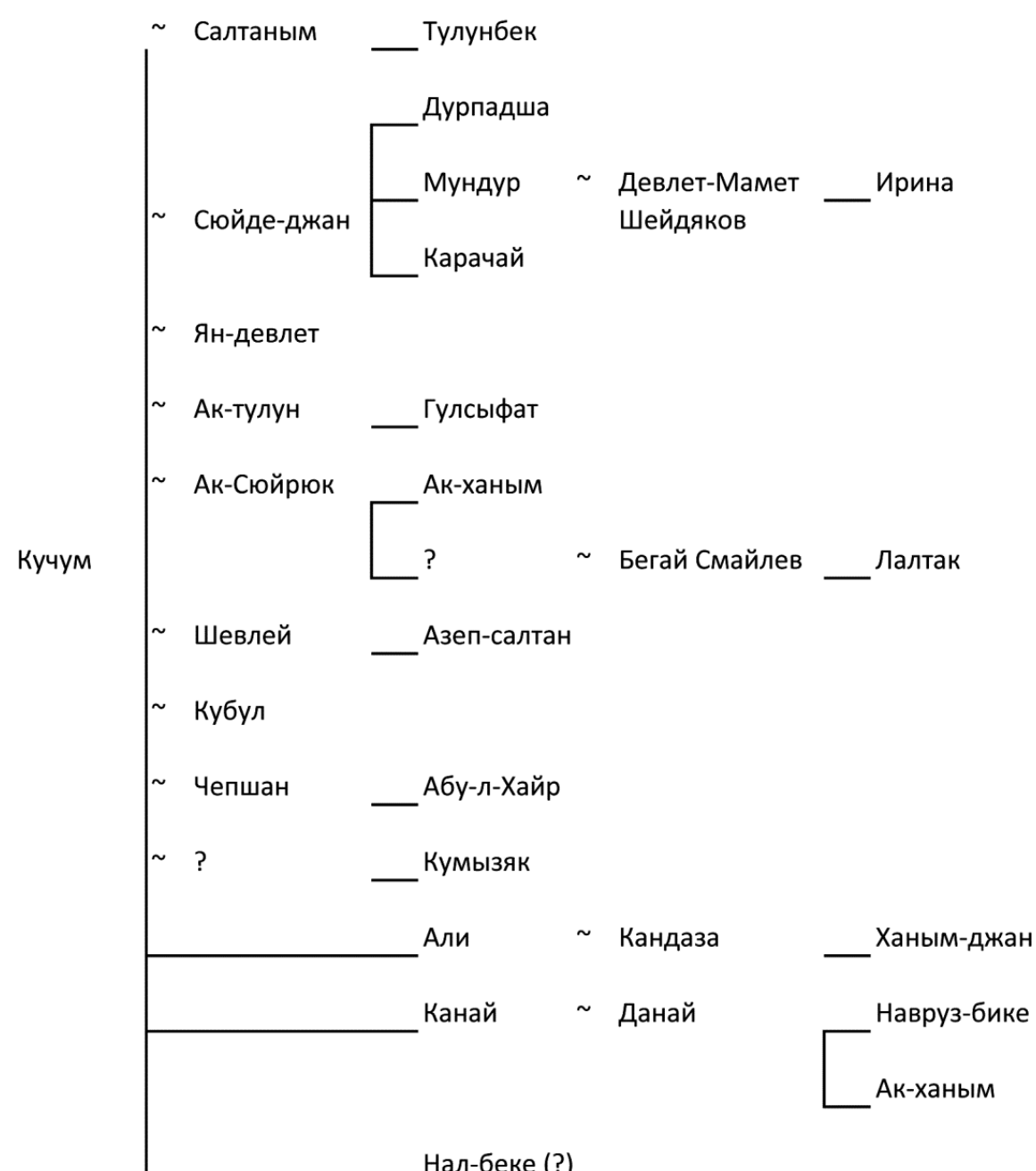

Женщины семьи хана Кучума в России

Women of the Kuchum Khan's family in Russia

\section{СПИСОК ЛИТЕРАТУРЫ}

1. Акты времени междуцарствования (1610 г. 17 июля - 1613 г.). М.: Типография Г. Лисскера и Д. Совко, 1915. 264 с.

2. Акты исторические, собранные и изданные Археографическою комиссиею. СПб.: Тип. ІІ-го Отделения Собственной Е.И.В. Канцелярии, 1841. Т. II. 482 с.

3. Антонов А.В. Землевладельцы Романовского уезда по материалам писцовой книги 1593-1594 годов // Архив русской истории. М.: Древлехранилище, 2007. C. 574-601.

4. Анхимюк Ю.В. Разрядная книга 1598-1602 годов // Русский дипломатарий. М.: Древлехранилище, 2003. Вып. 9. С. 361-413. 
5. Атыгаев Н.А. Хронология правления казахских ханов (XV - середины XVI в.) // Тюркологический сборник. М.: Восточная литература, 2007. С. 50-62.

6. Беляков A.B. Араслан Алеевич - последний царь касимовский // Рязанская старина. 2004-2005. Рязань: Край, 2006. Вып. 2-3. С. 8-31.

7. Беляков A.B. Исиней Карамышев сын Мусаитов. Неизвестный герой Смутного времени // Вестник Нижегородского университета им. Н.И. Лобачевского. 2012. №6. Часть 3. С. $82-87$.

8. Беляков А.В. Как звали большого сибирского карачу? // История, экономика и культура средневековых тюрко-татарских государств Западной Сибири. Материалы II Всероссийской научной конференции (Курган, 17-18 апреля 2014г.). Кургар: Издво Курганского гос. ун-та, 2014. С. 63-64.

9. Беляков А.B. О времени и месте написания продолжения сочинения Утемишхаджи «Кара таварих» (комментарии к тексту) // Золотоордынское обозрение. 2018. T. 6, №. 2. C. 370-392.

10. Беляков A.B. Сибирские выходцы в России в начале XVII в. Новые находки // История, экономика и культура средневековых тюрко-татарских государств Западной Сибири: материалы III Всероссийской (с международным участием) научной конференции (Курган, 21-22 апреля 2017 г.). Курган: Изд-во Курганского гос. ун-та, 2017. C. $84-86$.

11. Беляков А.В. Служащие Посольского приказа 1645 - 1682 гг. СПб.: НесторИстория, 2017. $368 \mathrm{c}$.

12. Беляков А.В. Ураз-Мухаммед ибн Ондан // Мининские чтения: 2006. Н. Новгород: Изд-во ННГУ, 2007. С. 29-59.

13. Беляков А.В. Царевич Авган-Мухаммед ибн Араб-Мухаммед в России первой половины XVII в. // Тюркологический сборник: 2006. М.: Восточная литература, 2007. C. $95-112$.

14. Беляков А.В. Чингисиды в России XV-XVII веков: просопографическое исследование. Рязань: Рязань. Мір, 2011. 512 с.

15. Беляков А.В., Виноградов А.В., Моисеев М.В. Институт аталычества в постзолотоордынском мире // Золотоордынское обозрение. 2017. Т. 5. №2. С. 412-436.

16. Беляков А.В., Енгальчева Г.А. Документы о происхождении толмачей Посольского приказа Кучумовых // Вестник Нижегородского университета им. Н.И. Лобачевского. 2017. №2. С. 16-23.

17. Беляков А.В., Маслюженко Д.Н. Сибирско-бухарско-ногайские отношения в свете переписки бухарского хана Абдаллаха с сибирским ханом Кучумом // Stratum plus. 2016. № 6: Pax Mongolica и европейские потрясения XIII-XIV вв. С. 229-243.

18. Беляков А.В., Моисеев М.В. Сююн-бике: из ногайских степей в касимовские царицы // Материалы и исследования по рязанскому краеведению. Рязань: РИОРО, 2004. T. 5. C. $32-44$.

19. Вельяминов-Зернов В.В. Исследование о касимовских царях и царевичах. СПб.: Тип. Императорской Академии наук, 1864. Ч. 2. 520 с.

20. Вельяминов-Зернов В.В. Исследование о касимовских царях и царевичах. СПб.: Тип. Императорской Академии наук, 1866. Ч. 3. 521 с.

21. Груневег M. (о. Венцеслав): духовник Марины Мнишек. Записки о торговой поездке в Москву в 1584-1585 гг. М.: Памятники исторической мысли, 2013. 384 с.

22. Документы Печатного приказа (1613-1615 гг.). М.: Наука, 1994. 479 с.

23. Зайщев И.В. Потомки Чингисхана в Москве и Стамбуле: сравнительный анализ / Чингисиды в России: «золотой род» после падения Золотой Орды // Российская история. 2013. №3. С. 21-23.

24. История татар с древнейших времен в семи томах. Казань: Институт истории им. Ш. Марджани АН РT, 2014. T. IV: Татарские государства XV - XVIII вв. 1080 с.

25. Казахско-русские отношения в XVI-XVIII вв. Алма-Ата: АН Казахской ССР, $1961.741 \mathrm{c}$. 
26. Мархочүкий Н. История Московской войны. М.: РОССПЭН, 2000. 223 с.

27. Маслюженко Д.Н. Этнополитическая история лесостепного Притоболья в средние века. Курган: Изд-во Курганского гос. университета, 2008. 168 с.

28. Маслюженко Д.Н., Рябинина Е.А. Брачная политика правителей Тюменского и Сибирского ханств // Средневековые тюрко-татарские государства. 2017. № 9. С. 103-109.

29. Материалы по истории Башкирской АССР. М.; Л. Изд-во АН СССР, 1936. $632 \mathrm{c}$.

30. Миллер Г.Ф. История Сибири. М.: Восточная литература, 2000. Т. II. 796 с.

31. Моисеев М.B. Землевладение служилых татар в Коломенском уезде в конце XVI в.(предварительные замечания) // Вестник университета Дмитрия Пожарского. 2017. №2. C. 236-247.

32. Моисеев М.B. К истории землевладения рода Юсуповых в начале XVII века // Русский дипломатарий. М.: Древлехранилище, 2004. Вып. 10. С. 197-202.

33. Некрасов А.М. Избранные труды. Нальчик.: Издательский отдел КБИГИ, 2015. $255 \mathrm{c}$.

34. Писцовые книги XVI в. СПб.: Типография Второго Отделения Собственной Е.И.В. Канцелярии, 1872. Отделение І.: местности губерний Московской, Владимирской, Костромской. 924 с.

35. Посольская книга по связям Московского государства с Крымом 15711577 гг. М.: Издательский дом Марджани, 2016. 400 с.

36. Русский архив Яна Петра Сапеги 1608-1611 годов. Текст, переводы, комментарии. Волгоград: Изд-во Волгоградского филиала ФГБОУ ВПО РАНХиГС, 2012. $688 \mathrm{c}$.

37. Собрание государственных грамот и договоров. М.: Тип. Селивановского, 1819. T. II. 399 c.

38. Трепавлов B.B. Сибирский юрт после Ермака: Кучум и Кучумовичи в борьбе за реванш. М.: Восточная литература, 2012. 231 с.

39. Трепавлов В.В., Беляков А.В. Сибирские царевичи в истории России. СПб.: Олег Абышко, 2018. 496 с.

40. Трутовский B.K. Надгробные надписи из Текие Афган Мохаммед Султана в г. Касимове // Труды Рязанской ученой архивной комиссии. Рязань: Типография Губернского правления, 1891. Т. V. С. 149-153.

Сведения об авторе: Андрей Васильевич Беляков- доктор исторических наук, старший научный сотрудник Института российской истории Российской академии наук (117292, ул. Дм. Ульянова, 19, Москва, Российская Федерация). E-mail: belafeb@gmail.com

Поступила 15.01.2019 Принята к публикащии 05.05.2019

Опубликована 29.06.2019

\section{REFERENCES}

1. Akty vremeni mezhdutsarstvovaniya (1610 g. 17 iyulya - 1613 g.) [Acts of the time of interregnum (1610, July 17 - 1613).]. Moscow: Tipografiya G. Lisskera i D. Sovko, 1915. 264 p. (In Russian)

2. Akty istoricheskie, sobrannye i izdannye Arkheograficheskoyu komissieyu. [Historical acts collected and published by the Archeographical Commission.] St. Petersburg: Tip. II-go Otdeleniya Sobstvennoy E.I.V. Kantselyarii, 1841. Vol. II. 482 p. (In Russian) 
3. Antonov A.V. Zemlevladel'tsy Romanovskogo uezda po materialam pistsovoy knigi 1593-1594 godov. [Landowners of the Romanovskiy district based on materials from the scribal book of 1593-1594]. Arkhiv russkoy istorii = Archive of Russian history. Moscow: Drevlekhranilishche, 2007, pp. 574-601. (In Russian)

4. Ankhimyuk Yu.V. Razryadnaya kniga 1598-1602 godov. [The Official Order Book of 1598-1602]. Russkiy diplomatariy = Russian diplomatary. Moscow: Drevlekhranilishche, 2003. Is. 9, pp. 361-413. (In Russian)

5. Atygaev N.A. Khronologiya pravleniya kazakhskikh khanov (XV - serediny XVI v.). [Chronology of the rule of the Kazakh Khans $\left(15^{\text {th }}-\right.$ middle of the $16^{\text {th }}$ century)] Tyurkologicheskiy sbornik = Turkological collection. Moscow: Vostochnaya literatura, 2007, pp. 50-62. (In Russian)

6. Belyakov A.V. Araslan Aleevich - posledniy tsar' kasimovskiy [Araslan Aleevich The Last Tsar of Kasimov]. Ryazanskaya starina = Olden Time of Ryazan. 2004-2005. Ryazan: Kray, 2006. Is. 2-3, pp. 8-31. (In Russian)

7. Belyakov A.V. Isiney Karamyshev syn Musaitov. Neizvestnyy geroy Smutnogo vremeni. [Isine Karamyshev son of Musait. Unknown Hero of the Time of Troubles]. Vestnik Nizhegorodskogo universiteta im. N.I. Lobachevskogo $=$ Bulletin of N.I. Lobachevsky Nizhny Novgorod University. 2012, no. 6. Chast' 3, pp. 82-87. (In Russian)

8. Belyakov A.V. Kak zvali bol'shogo sibirskogo karachu? [What was the name of the great Siberian Karachu?]. Istoriya, ekonomika i kul'tura srednevekovykh tyurko-tatarskikh gosudarstv Zapadnoy Sibiri. Materialy II Vserossiyskoy nauchnoy konferentsii (Kurgan, 17-18 aprelya 2014g.) = History, economy and culture of medieval Turkic-Tatar states of Western Siberia. Proceedings of the II All-Russian Research Conference (Kurgan, April 17-18, 2014). Kurgar: Kurgan State University Publ., 2014, pp. 63-64. (In Russian)

9. Belyakov A.V. O vremeni i meste napisaniya prodolzheniya sochineniya Utemishkhadzhi «Kara tavarikh» (kommentarii k tekstu). [On the Time and Place of Writing the Continuation of Ötemish-Hajji's "Qara Tavarikh" (Comments on the Text)] Zolotoordynskoe obozrenie $=$ Golden Horde Review. 2018, vol. 6, no. 2, pp. 370-392. (In Russian)

10. Belyakov A.V. Sibirskie vykhodtsy v Rossii v nachale XVII v. Novye nakhodki. [Siberian immigrants in Russia at the beginning of the $17^{\text {th }}$ century. New finds]. Istoriya, ekonomika $i$ kul'tura srednevekovykh tyurko-tatarskikh gosudarstv Zapadnoy Sibiri: materialy III Vserossiyskoy (s mezhdunarodnym uchastiem) nauchnoy konferentsii (Kurgan, 21-22 aprelya 2017 g.) = History, economics and culture of medieval Turkic-Tatar states of Western Siberia: Proceedings of the III All-Russian (with international participation) Research Conference (Kurgan, April 21-22, 2017). Kurgan: Kurgan State University Publ., 2017, pp. 84-86. (In Russian)

11. Belyakov A.V. Sluzhashchie Posol'skogo prikaza 1645-1682 gg. [Employees of the Embassy Order in 1645-1682]. St. Petersburg: Nestor-Istoriya, 2017. 368 p. (In Russian)

12. Belyakov A.V. Uraz-Mukhammed ibn Ondan. [Uraz-Mohammed ibn Ondan] Mininskie chteniya: $2006=$ Minin readings: 2006. N. Novgorod: N. Novgorod State Universitet Publ., 2007, pp. 29-59. (In Russian)

13. Belyakov A.V. Tsarevich Avgan-Mukhammed ibn Arab-Mukhammed v Rossii pervoy poloviny XVII v. [Tsarevich Avgan-Mohammed ibn Arab-Mohammed in Russia in the first half of the $17^{\text {th }}$ century] Tyurkologicheskiy sbornik: $2006=$ Turkological collection: 2006. Moscow: Vostochnaya literatura, 2007, pp. 95-112. (In Russian)

14. Belyakov A.V. Chingisidy v Rossii XV - XVII vekov: prosopograficheskoe issledovanie. [The Chinggisids in Russia of the $15^{\text {th }}-17^{\text {th }}$ centuries: prosopographic research]. Ryazan: Ryazan. Mir, 2011. 512 p. (In Russian)

15. Belyakov A.V., Vinogradov A.V., Moiseev M.V. Institut atalychestva v postzolotoordynskom mire [Institution of Atalykship in the Post-Golden Horde World]. Zolotoordynskoe obozrenie $=$ Golden Horde Review. 2017, vol. 5, no. 2, pp. 412-436. (In Russian) 
16. Belyakov A.V., Engalycheva G.A. Dokumenty o proiskhozhdenii tolmachey Posol'skogo prikaza Kuchumovykh. [Documents on the origin of interpreters of the Ambassadors Order of the Kuchumovs]. Vestnik Nizhegorodskogo universiteta im. N.I. Lobachevskogo $=$ Bulletin of N.I. Lobachevsky Nizhny Novgorod University. 2017, no. 2, pp. 16-23. (In Russian)

17. Belyakov A.V., Maslyuzhenko D.N. Sibirsko-bukharsko-nogayskie otnosheniya v svete perepiski bukharskogo khana Abdallakha s sibirskim khanom Kuchumom. [SiberianBukhara-Nogai relations in the light of the correspondence of Bukhara Khan Abdullah with the Siberian Khan Kuchum]. Stratum plus. 2016, no. 6: Pax Mongolica i evropeyskie potryaseniya XIII-XIV vv., pp. 229-243. (In Russian)

18. Belyakov A.V., Moiseev M.V. Syuyun-bike: iz nogayskikh stepey v kasimovskie tsaritsy [Syuyun-Bike: From the Nogai steppes to Kasimov's queen]. Materialy $i$ issledovaniya po ryazanskomu kraevedeniyu = Materials and research on Ryazan regional studies. Ryazan': RIORO, 2004. VOL. 5, pp. 32-44. (In Russian)

19. Vel'yaminov-Zernov V.V. Issledovanie o kasimovskikh tsaryakh i tsarevichakh [Study on the Kasim's tsars and princes] St. Petersburg: Tip. Imperatorskoy Akademii nauk, 1864. Ch. 2. 520 p. (In Russian)

20. Vel'yaminov-Zernov V.V. Issledovanie o kasimovskikh tsaryakh i tsarevichakh [Study on the Kasim's tsars and princes]. St. Petersburg: Tip. Imperatorskoy Akademii nauk, 1866. Part III. 521 p. (In Russian)

21. Gruneveg M. (o. Ventseslav): confessor of Marina Mnishek. Zapiski o torgovoy poezdke v Moskvu v 1584-1585 gg. [Notes about the trade trip to Moscow in 1584-1585]. Moscow: Pamyatniki istoricheskoy mysli, 2013. 384 p. (In Russian)

22. Dokumenty Pechatnogo prikaza (1613-1615 gg.). [Printed Order Documents (1613-1615)]. Moscow: Nauka Publ., 1994. 479 p. (In Russian)

23. Zaytsev I.V. Potomki Chingiskhana v Moskve i Stambule: sravnitel'nyy analiz / Chingisidy v Rossii: «zolotoy rod» posle padeniya Zolotoy Ordy. [The descendants of Chinggis Khan in Moscow and Istanbul: a comparative analysis / The Chinggisids in Russia: The "Golden Kin" after the fall of the Golden Horde]. Rossiyskaya istoriya = Russian history. 2013, no. 3, pp. 21-23. (In Russian)

24. Istoriya tatar $s$ drevneyshikh vremen $v$ semi tomakh [The history of the Tatars from ancient times in seven volumes]. Kazan: Marjani Institute of History of Tatarstan Academy of Sciences, 2014. T. IV: Tatarskie gosudarstva XV-XVIII vv. [Tatar States of the $15^{\text {th }}-18^{\text {th }}$ centuries.] 1080 p. (In Russian)

25. Kazakhsko-russkie otnosheniya v XVI-XVIII vv. [Kazakh-Russian relations in the $16^{\text {th }}-18^{\text {th }}$ centuries.]. Alma-Ata: AN Kazakhskoy SSR, 1961. $741 \mathrm{p}$.

26. Markhotskiy N. Istoriya Moskovskoy voyny [History of the Moscow War]. Moscow: ROSSPEN, 2000. 223 p. (In Russian)

27. Maslyuzhenko D.N. Etnopoliticheskaya istoriya lesostepnogo Pritobol'ya $v$ srednie veka [Ethnopolitical history of the forest-steppe Tobol region in the Middle Ages]. Kurgan: Kurgan State Universitet Publ., 2008. 168 p. (In Russian)

28. Maslyuzhenko D.N., Ryabinina E.A. Brachnaya politika praviteley Tyumenskogo i Sibirskogo khanstv. [The marriage policy of the rulers of the Tyumen and Siberian Khanates]. Srednevekovye tyurko-tatarskie gosudarstva = Medieval Turkic-Tatar states. 2017, no. 9, pp. 103-109. (In Russian)

29. Materialy po istorii Bashkirskoy ASSR [Materials on the history of the Bashkir ASSR]. Moscow: Leningrad: Akademiya nauk SSSR, 1936. 632 p. (In Russian)

30. Miller G.F. Istoriya Sibiri [Siberian history] Moscow: Vostochnaya literatura, 2000. Vol. II. 796 p. (In Russian)

31. Moiseev M.V. Zemlevladenie sluzhilykh tatar v Kolomenskom uezde v kontse XVI v.(predvaritel'nye zamechaniya). [Land tenure of the Service Tatars in the Kolomna district at the end of the $16^{\text {th }}$ century (preliminary observations)]. Vestnik universiteta 
Dmitriya Pozharskogo = Bulletin of Dmitry Pozharsky University. 2017, no. 2, pp. 236247. (In Russian)

32. Moiseev M.V. K istorii zemlevladeniya roda Yusupovykh v nachale XVII veka. [To the history of land tenure of the Yusupov family in the early $17^{\text {th }}$ century]. Russkiy diplomatariy $=$ Russian diplomatary. Moscow: Drevlekhranilishche, 2004. Is. 10, pp. 197202. (In Russian)

33. Nekrasov A.M. Izbrannye trudy [Selected Works]. Nal'chik: Izdatel'skiy otdel KBIGI, 2015. 255 p. (In Russian)

34. Pistsovye knigi XVI v. [Scribe books of the $16^{\text {th }}$ century.] St. Petersburg: Tipografiya Vtorogo Otdeleniya Sobstvennoy E.I.V. Kantselyarii, 1872. Otdelenie I.: mestnosti guberniy Moskovskoy, Vladimirskoy, Kostromskoy [Areas of the Moscow, Vladimir, Kostroma provinces]. 924 p. (In Russian)

35. Posol'skaya kniga po svyazyam Moskovskogo gosudarstva s Krymom 1571-1577 gg. [The ambassadorial book on relations of the Moscow State with the Crimea in 15711577.]. Moscow: Mardzhani Publ., 2016. 400 p. (In Russian)

36. Russkiy arkhiv Yana Petra Sapegi 1608-1611 godov. Tekst, perevody, kommentarii [The Russian Archive of Jan Petr Sapieha for the years 1608-1611. Text, translations, comments]. Volgograd: Izd-vo Volgogradskogo filiala FGBOU VPO RANKhiGS, 2012. 688 p. (In Russian)

37. Sobranie gosudarstvennykh gramot i dogovoro. [Collection of state certificates and treaties]. Moscow: Tip. Selivanovskogo, 1819. Vol. II. 399 p. (In Russian)

38. Trepavlov V.V. Sibirskiy yurt posle Ermaka: Kuchum i Kuchumovichi v bor'be za revansh [Siberian Yurt after Ermak: Kuchum and Kuchumovichi in the fight for revenge]. Moscow: Vostochnaya literatura, 2012. 231 p. (In Russian)

39. Trepavlov V.V., Belyakov A.V. Sibirskie tsarevichi v istorii Rossii [Siberian princes in the history of Russia]. St. Petersburg: Oleg Abyshko, 2018. 496 p. (In Russian)

40. Trutovskiy V.K. Nadgrobnye nadpisi iz Tekie Afgan Mokhammed Sultana v g. Kasimove. [Gravestone inscriptions from Tekie of Afgan Mohammed Sultan in Kasimov] Trudy Ryazanskoy uchenoy arkhivnoy komissii = Proceedings of the Ryazan Scientific Archival Commission. Ryazan': Tipografiya Gubernskogo pravleniya, 1891. Vol. V, pp. 149-153. (In Russian)

About the autor: Andrey V. Belyakov - Dr. Sci. (History), Research Associate, Institute of Russian History of the Russian Academy of Sciences (19, Dm. Ulyanov Str., Moscow 117292, Russian Federation). E-mail: belafeb@gmail.com 